\title{
In Search of the Carbohydrate Structures on CD44 Critical for Hyaluronic Acid Binding - Roles of Sialylation and Sulfation
}

\section{CD44 のヒアルロン酸結合能に重要な役割を演じる糖鎖修飾 一シアル酸基と硫酸基の意義}

\author{
Kannagi, Reiji* ; Goto, Yoshiko ; and Fukui, Fumiyo \\ ${ }^{*}$ To whom correspondence should be addressed. \\ Division of Molecular Pathology, Aichi Cancer Center Research Institute, 1-1 Kanokoden, Chikusa-ku, Nagoya 464-8681, Japan \\ FAX: 81-52-764-2973, E-mail: rkannagi@ aichi-cc.jp
}

Key Words: activation of hyaluronic acid binding, CD44-deficient mice, TNF $\alpha$, desialylation, 6-sulfation, dendritic cells

\begin{abstract}
CD44 is a transmembrane adhesion molecule involved in cell-cell and cell-extracellular matrix interactions. It contains a functional hyaluronic acid-binding domain and serves as a major cell surface receptor for hyaluronic acid. It mediates recruitment of various types of cells and their motility in interstitial tissues of numerous organs. Cell adhesion mediated by CD44 has generally been assumed to enhance inflammatory response and cancer progression. Recent findings using CD44-deficient mice indicated that CD44 may not be an indispensable molecule for embryonic development and maintenance of life, but it remains clear that CD44 plays an important role in many pathological processes through its binding activity to hyaluronic acid. Glycosylation of CD44 is known to have a prominent effect on its hyaluronic acid binding activity. Usually CD44 expressed at the cell surface does not constitutively bind hyaluronic acid, and some activation process is necessary to attain effective hyaluronic acid binding. Recent findings indicated that specific changes in glycosylation of CD44 induced in stimulated cells play an essential role in the activation of hyaluronic acid binding. Two kinds of specific changes in its carbohydrate side chains were identified to be induced in stimulated cells, and figure heavily in the activation of hyaluronic acid binding; one is desialylation by an endogenous sialidase, and the other is enhancement of 6-sulfation in glycans carried by CD44.
\end{abstract}

要 約

CD44は多様な細胞-細胞間および細胞-細胞マトリックス間 の接着を媒介する細胞接着分子である。ヒアルロン酸との結合 能をもち、細胞の主要なヒアルロン酸結合蛋白質の一つであ る。CD44を介した細胞接着は、一般に炎症を充進させ、癌の進 展をプロモートすると考えられて来た。最近のCD44ノックア ウトマウスについての解析から、必ずしも個体発生や生命の維 持において不可欠な分子ではないことが判明してきたが、CD44 がヒアルロン酸への結合を介してさまざまな疾患の病態発生に おいて重要な役割を演じていることは疑いをいれない。CD44分 子の糖鎖修飾が、この分子のヒアルロン酸への結合能を左右す ることは良く知られている。多くの場合、細胞表層に発現され たCD44 はそのままではヒアルロン酸への結合能を持たず、活 性化刺激によってはじめてヒアルロン酸結合能をあらわすよう になる。最近の研究の進展によって、細胞刺激に伴う CD44の 糖鎖修飾の変化が、ヒアルロン酸結合能の誘導に主要な役割を 演じることが明らかになってきた。なかでも次の二通りの糖鎖 修飾の変化が重要である。一つは内因性シアリダーゼによる CD44 の脱シアル酸化であり、もうひとつは糖鎖の GlcNAc-6-硫 酸化修飾である。

\section{A. Introduction}

CD44 is a transmembrane adhesion molecule, which specifically binds hyaluronic acid. CD44 is involved in cell-cell and cell-extracellular matrix interactions, and is implicated also in uptake and degradation of hyaluronic acid. It has become evident that intricate posttranslational modification of CD44 regulates its binding activity to hyaluronic acid, including glycosylation, phosphorylation, palmitoylation and proteolytic modification (reviewed in (1-7)). This minireview will focus on emerging evidence showing the critical role of glycosylation in the regulation of hyaluronic acid binding activity of CD44.

\section{A. はじめに}

CD44 はヒアルロン酸との結合能をもつ細胞接着分子であ る。CD44 は多様な細胞-細胞間および細胞-細胞マトリックス間 の接着を媒介しており、また、組織中のヒアルロン酸の代謝回 転に関与している。CD44 のヒアルロン酸結合能の調節におい て、この分子の糖鎖修飾・リン酸化・パルミトイル化・タンパ ク分解酵素による切断、などといったさまざまの翻訳後修飾が 重要な役割を持つことが明らかになっている。この点について は最近の総説 (1-7) に詳しい。特にCD44 の糖鎖修飾がヒアル ロン酸結合能の調節において重要な役割を演じることが最近つ 


\section{B. Molecular Structure of CD44 and its Glycosylation}

CD44 is encoded by a single gene consisting of at least 20 exons, and multiple isoforms are known to emerge by alternative RNA splicing (Fig. 1). The most abundant and widely expressed CD44 is encoded by 10 exons, and is hence named CD44 standard (CD44S). It consists of an $\mathrm{N}$-terminal signal peptide sequence (encoded by invariant exon 1), a hyaluronic acid binding domain (exons 2 and 3), a stem region (exons 4, 5, 6,7 ), a transmembrane domain (exon 8), and a cytoplasmic domain (exon 9 or 10). CD44S is typically found on leukocytes, and also called CD44H (hematopoietic CD44). On the other hand, endothelial and epithelial cells express high molecular CD44 isoforms, which are produced by the insertion of alternative exons (v1-v10) at a single site within the stem region (Fig. 1). A high molecular form of CD44 in epithelial cells was named CD44E or epican.

$\mathrm{CD} 44$ is highly glycosylated with multiple $N$ - and $O$-gly-
ぎつぎと明らかになってきた。このミニレビューでは CD44の 糖鎖修飾に焦点を絞って解説する。

\section{B. CD44 の分子構造とその糖鎖修飾}

CD44 遺伝子は少なくとも 20 のエキソンから成り、選択的 スプライシングによって多種多様な分子種を生じる (図 1)。諸 組織に最も広く発現しているCD44 は 10 のエキソンによって コードされ、CD44S (Standard CD44)と呼ばれている。エキソン 1 はN $\mathrm{N}$ 末グナルペプチドをコードし、以下 CD44 分子はヒア ルロン酸結合領域(エキソン 2 と 3 )、基幹領域(エキソン 4 7)、 細胞膜貫通領域 (エキソン 8)、細胞内領域 (エキソン 9 または 10)とから成る。CD44S は白血球などの造血細胞に発現されるの で、CD44H (Hematopoietic CD44) とも呼ばれる。一方、血管内 皮細胞や上皮細胞には高分子量の CD44 イソフォームが発現さ れている。これらはバリアントエキソン $(\mathrm{v} 1 \sim \mathrm{v} 10)$ が基幹領域 の特定の場所に挿入されることによって生じる分子種である (図 1)。上皮細胞の高分子量の CD44 イソフォームは CD44E やエピ カンと呼ばれている。

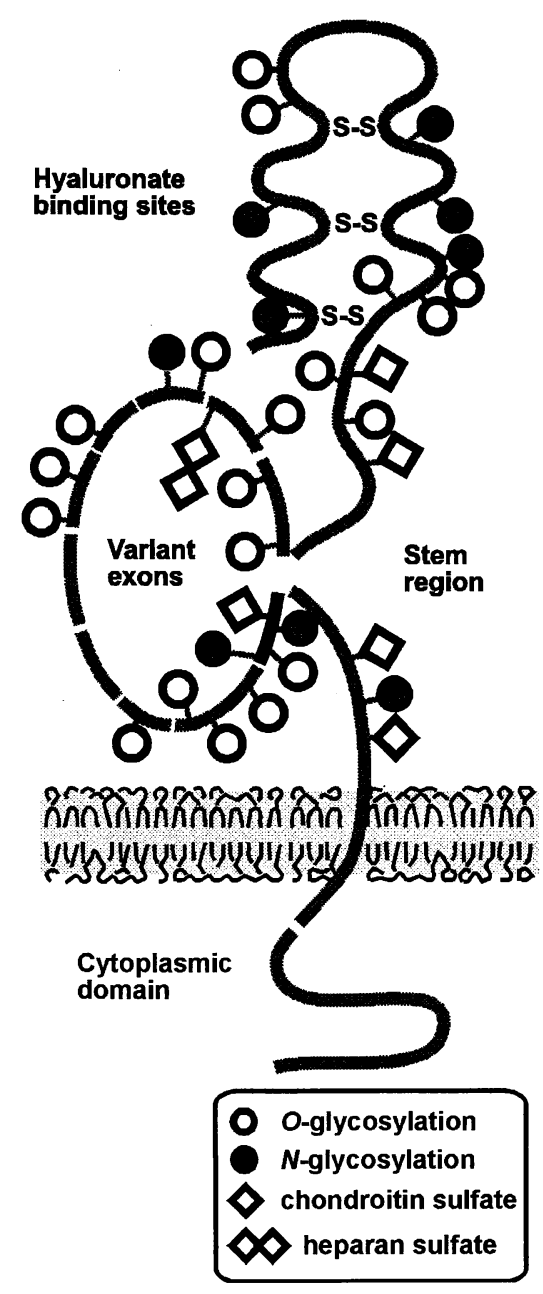

Fig. 1. Schematic representation of CD44 structure, the heavily glycosylated cell adhesion molecule. CD44 consists of a hyaluronic acid binding domain, a stem region, a transmembrane domain, and a cytoplasmic domain. High molecular CD44 isoforms are produced by insertion of variant exons at a single site within the stem region by alternative splicing. Cytoplasmic tails of CD44 isoforms vary in size as the result of alternative splicing. 
Trends in Glycoscience and Glycotechnology Vol.16 No.89 (May 2004) pp.211-223

cans as well as glycosaminoglycans $(8,9)$. The molecular mass for $\mathrm{CD} 44 \mathrm{H}$ calculated from amino acid residues is $-37 \mathrm{kDa}$, while the apparent molecular mass of $\mathrm{CD} 44 \mathrm{H}$ from cells and tissues as estimated by gel electrophoresis is $80-90 \mathrm{kDa}$, due to the extensive modification by $\mathrm{N}-, \mathrm{O}$-glycans and glycosaminoglycans. The hyaluronic acid binding domain of $\mathrm{CD} 44 \mathrm{H}$ is equipped with at least 5 conserved consensus $N$-glycosylation sites, multiple $O$-glycosylation sites along with two Ser-Gly motifs that support attachment of chondroitin, but not heparan, sulfate. Additional two Ser-Gly motifs are present in the stem region.

CD44 isoforms with variant exons are the major cell surface chondroitin sulfate proteoglycan having the molecular mass of $-200 \mathrm{kDa}$ in endothelial cells and dermal epithelial cells. High molecular forms of CD44 are also known to appear on leukocytes upon activation. The alternatively spliced variable exon products also have extensive $O$ - and $N$-glycosylation sites and Ser-Gly motifs for chondroitin sulfate attachment. The variant exon v3 has a Ser-Gly-Ser-Gly motif that supports both chondroitin and heparan sulfate attachment, and v10 has a SerGly motif (10). In some cells the CD44 isoforms containing v3 are known to be modified by heparan sulfate, and were shown to bind heparin-binding growth factors and cytokines including chemokines.

\section{Roles of CD44 in Inflammation and Malignant Progression}

More than a decade has elapsed since CD44 was first identified as a leukocyte antigen by the monoclonal antibody approach. Since then numerous studies have been carried out to elucidate possibly important physiological functions of this molecule. In those studies CD44 has generally been considered to be involved in the extravasation of leukocytes in inflammatory diseases, which leads to exacerbation of inflammatory diseases such as rheumatoid arthritis. CD44 was also proposed to promote tumorigenesis and malignant behavior of cancers such as metastasis. This situation was very similar to that of another cell adhesion molecule, selectin, which is involved in inflammatory leukocyte extravasation and also in hematogenous metastasis of cancer cells (11-13). The paradigm for CD44 and that for selectin had been very similar in that the metastasizing tumor cells mimic leukocyte behavior.

With CD44, however, the earlier proposals for physiological significance of the molecule should be reconsidered in the light of the recent results obtained using CD44-deficient mice. Surprisingly, the CD44-deficient mice generated independently in two laboratories reportedly exhibited no overt abnormalities $(14,15)$.

CD44 is regarded as a cell adhesion and homing molecule. It had been proposed that CD44 is involved in the homing of lymphocytes to peripheral lymph nodes as well as Lselectin. In contrast to L-selectin deficient mice, however, CD44-

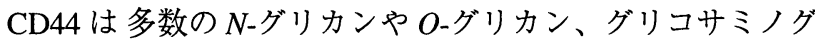
リカン鎖によって活発に糖鎖修飾されている $(8 、 9)$ 。アミノ酸残 基から計算すると $\mathrm{CD} 44 \mathrm{H}$ の分子量は $37 \mathrm{kDa}$ 程度であるが、細 胞や組織から得られる CD44H の電気泳動上の分子量は 80〜90 $\mathrm{kDa}$ であり、糖鎖修飾がきわめて盛んにおこっていることがわか る。ヒアルロン酸結合領域には少なくとも 5 個の $N$-グリカン結 合部位があり、O-グリカン結合部位もいくつか存在するほか、 コンドロイチン硫酸が結合する Ser-Gly モチーフが 2 個存在す る。このモチーフにはコンドロイチン硫酸は結合するが、ヘパ ラン硫酸は結合しないとされる。基幹領域にはこのような SerGly モチーフがさらに2 個存在する。

バリアントエキソンを発現する CD44 イソフォームは 200 $\mathrm{kDa}$ 程度の分子量をもち、血管内皮細胞や皮膚の上皮細胞で主要 なコンドロイチン硫酸プロテオグリカンとなっている。白血球 においても、刺激によっては高分子量の CD44 イソフォームが 発現する。バリアントエキソンにも多数の $N$-グリカンやO-グリ カン結合部位が存在するほか、Ser-Gly モチーフも存在する。特 にバリアントエキソン v3 には Ser-Gly-Ser-Gly モチーフが存在 し、細胞によりコンドロイチン硫酸ないしへパラン硫酸が結合 する(10)。ヘパラン硫酸によってバリアントエキソン v3 が修飾 されると、細胞増殖分子やケモカインなどのサイトカインを結 合することが知られている。

\section{C. 炎症と腫瘍における CD44 の役割}

単クローン抗体を用いて CD44 が白血球の分化抗原の一つで あることが知られてから 20 年以上が経過し、この分子の生理的 機能についての研究もさかんに行われてきた。これまでの研究 では、CD44 は炎症に扔ける白血球の血管外脱出を媒介し、リウ マチ性関節炎などの炎症性病変を増悪させる働きをもつと考え られてきた。CD44はまた悪性腫瘍の発生を促進し、癌の転移を 引き起こすと考えられてきた。こうした考えは、同じく細胞接 着分子であるセレクチンについての考え方とたいへんよく似て いる。セレクチンもまた、白血球の血管外脱出を媒介し、他方 で癌の血行性転移を引き起こすと考えられている(11-13)。こう した考え方は、癌の転移には白血球の血管外脱出とょく似た機 構が㗢いているのだという共通のパラダイムに基づいている。

しかしながら CD44の場合には、こうしたこれまでのこの分 子の生理的意義についての考え方は、最近の CD44ノックアウト マウスから得られた成績によって再考をうながされていると云え よう。意外なことに、CD44ノックアウトマウスはすぐにそれと わかるような目立った異常を示さなかったのである (14、15)。

CD44 は細胞接着分子であり、ホーミング分子であるとされ てきた。L-セレクチンと同じように、CD44 もまたリンパ球の末 梢リンパ節へのホーミングに関与する分子と見なされてきた。 
deficient mice showed no significant decrease in normal lymphocyte homing to lymph nodes $(16,17)$, while a significantly impaired entry of immature lymphocytes into adult thymus and a moderately reduced entry of CFU-GM into spleen were observed in CD44-deficient mice $(14,15)$. Lack of contribution of CD44 in the lymphocyte homing to peripheral lymph nodes had already been predicted from the in vivo studies using neutralizing anti-CD44 antibodies (18). CD44 is also implicated in the extravasation of leukocytes in inflammatory lesion, which is partly supported by studies using CD44-deficient mice (17). CD44 is also involved in the motility of cells within several tissues and organs mediating interaction of various types of cells. Cell adhesion systems where CD44 is involved include interactions of leukocytes with synovial cells, cancer cells with mesothelial cells, and lymphoid cells with squamous or intestinal epithelial cells (19-25) (Figs. 2 and 3). These findings indicate that CD44-hyaluronic acid interaction plays a role in facilitating the recruitment of bone marrow immature cells and, to some extent, inflammatory leukocytes, while supporting the movement of leukocytes in interstitial tissues of various organs under physiological and pathological conditions.

Whether CD44-mediated cell adhesion would exacerbate or improve inflammatory diseases needs reconsideration. While several reports indicated a significant alleviation of leukocyte-
しかしながら、L-セレクチンノックアウトマウスの場合とは異 なり、CD44ノックアウトマウスではナイーブリンパ球のリンパ 節へのホーミングの異常は認められていない $(16 、 17) 。$ かわり に、未熟リンパ球の骨髄から胸腺への移動や、未熟血液幹細胞 の脾への移動が障害されていた $(14 、 15) 。 \mathrm{CD} 44$ がどうやらリン パ球の末梢リンパ節へのホーミングにあまり関与していないら しいことは、以前から in vivoで中和抗体を用いた実験成績から 示唆されていた(18)。CD44 は炎症に扔ける白血球の組織浸潤に 関与するとされてきたが、これはノックアウトマウスを用いた 一部の成績で支持された (17)。CD44 はまた、さまざまな細胞の いろいろな組織中での動態に関与するとされる。これまでに報 告されたものとしては、白血球の関節滑膜細胞への接着、癌細 胞の中皮細胞への接着、リンパ球系細胞の扁平上皮や腸管上皮 への接着などがある(図 2 および3) (19-25)。これらのことから、 CD44 は骨髄からの未分化細胞の動員に関与しており、また白血 球の炎症性浸潤にもある程度関与し、健常時ないし病的条件下 でそのほかのさまざまな細胞の組織間質での動態に関与すると 考えられる。

細胞の動態に関与するからといって、CD44が従来考えられ てきたように炎症疾患の増悪に関与するのか、あるいはむしろ 炎症病変を改善治癒する方向に働くのかという点については、

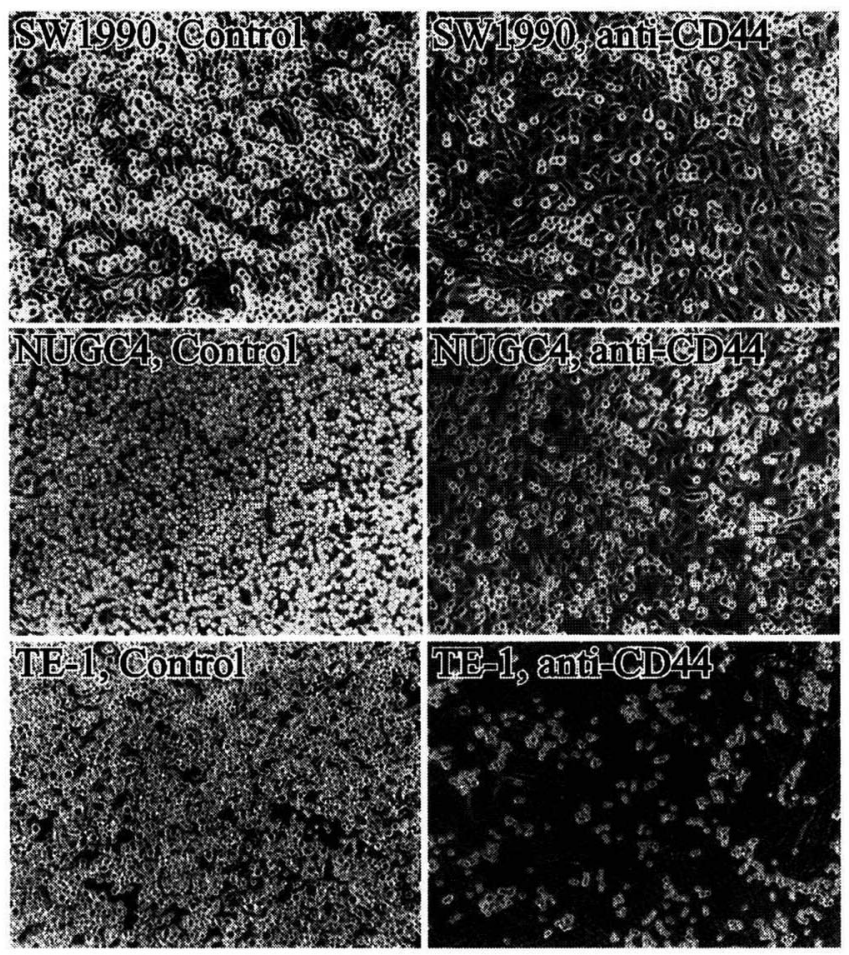

Fig. 2. CD44-mediated adhesion of human cancer cells to mesothelial cells. Adhesion of human pancreatic (SW1990), gastric (NUGC-4) or esophageal (TE-1) cancer cells to mesothelial cells, shown in the left panels, is significantly inhibited by the addition of anti-CD44 antibody (right panel). Monolayer of peritoneal mesothelial cells was used for SW1990 and NUGC-4, and that of pleural mesothelial cells was used for TE-1. 


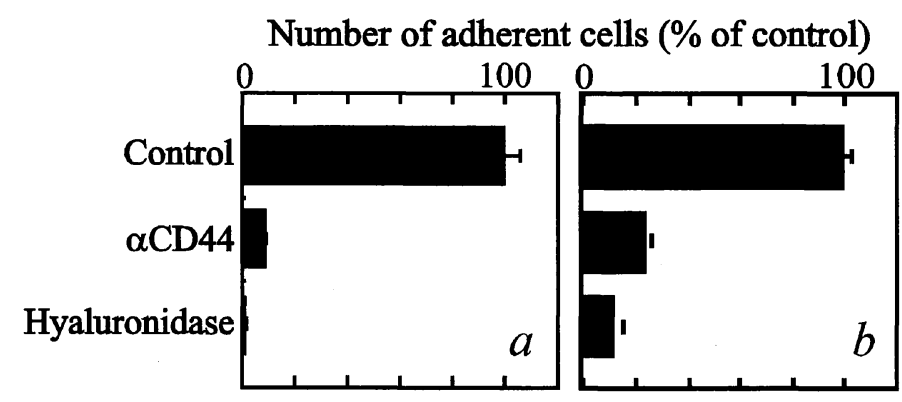

Fig. 3. Examples of CD44-mediated cell adhesion as ascertained by non-static monolayer cell adhesion assay. Panel $a$, adhesion of cultured lymphoid cells HUT78 to squamous epithelial cells; panel $b$, adhesion of human gastric cancer cells NUGC-4 to human peritoneal mesothelial cells. Cell adhesion was almost completely blocked by anti-CD44 treatment of lymphoid cells and gastric cancer cells $(2 \mu \mathrm{g} / \mathrm{ml})$. Cell adhesion was abrogated also by hyaluronidase treatment of squamous epithelial cells or mesothelial cells.

mediated blood vessel injury or tissue damage in CD44-deficient mice $(16,26,27)$, some other recent results revealed unexpected aspects of CD44 function in inflammation in these mice. For instance, CD44-deficient mice exhibited enhanced hepatitis after concanavalin A injection (28), or more severe leukocyte infiltration and lung injury after intratracheal bleomycin administration (29). CD44-deficient mice displayed much more tubular damage in the course of the renal disease following chronic obstructive nephropathy (30), and exhibited enhanced neutrophil migration and lung injury in an Escherichia coli-induced pneumonia model (31). The antigen response of $\mathrm{T}$ cells was enhanced in CD44-deficient mice, which was attributed to the lack of activation-induced $\mathrm{T}$ cell apoptosis in the deficient mice (32). These results suggested some anti-inflammatory aspect of CD44-mediated cell adhesion.

CD44 has been conventionally considered to act as a tumor-promoting factor. Although the roles of CD44 in promoting cancer metastasis was supported by some reports showing attenuation of metastasis in CD44-deficient mice (33), CD44-negative cells in CD44-deficient mice in general appear to be more susceptible to oncogenic transformation (14,34), suggesting some anti-tumor promoting effect of CD44-mediated cell adhesion. Even the earlier results obtained with human materials had been controversial. Expression of CD44 including v6 variant was shown to be increased and to be an indicative of a poor prognosis and metastasis in colon cancers, whereas its expression indicated a favorable prognosis in ovarian or prostate cancers $(35,36)$. Antisense cDNA induced suppression of CD44 expression in colon cancer cells and inhibited their malignant behavior (37), while overexpression of CD44 in prostate cancer cells suppressed their metastasis $(38,39)$. Several hypotheses reconciling these apparent discrepancies have been proposed (40).

These findings indicate that CD44 may not be an indispensable molecule for the development and maintenance of life, while being a potent modulator of various physiological and pathobiological events.
再検討を要する。CD44 欠損マウスでは白血球による血管内皮の 障害や組織傷害が軽減するとの報告はあるものの $(16 、 26 、 27) 、$ 意外にも CD44 欠損マウスで炎症が悪化するとの報告もある。 たとえばCD44 ノックアウトマウスでは Con A 投与による肝炎 が悪化する (28)、またブレオマイシン投与によって惹起される 白血球浸潤が正常マウスより充進する、といった報告がある (29)。CD44ノックアウトマウスでは腎疾患時の尿細管傷害が正 常マウスより重症となることや (30)、大腸菌による肺炎モデル で正常マウスよりむしろ白血球浸潤が強くなるという報告もあ る (31)。T 細胞の抗原応答は CD44 ノックアウトマウスではむ しろ増強しており、これは活性化 $\mathrm{T}$ 細胞のアポトーシスが欠如 しているためであろうと考えられている (32)。これらの成績 は、CD44 が何らかの意味で炎症を抑制する作用を持つことを示 唆している。

CD44 はしばしば悪性腫場の増悪因子ともみなされてきた。 CD44ノックアウトマウスを用いた成績でも、このマウスで転移 が抑制されているとの報告がたしかに一部にある (33)。しか し、CD44 ノックアウトマウス由来の CD44 陰性の細胞はむし

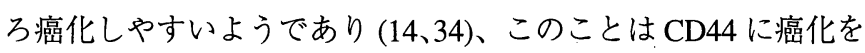
抑制する何らかの機能があることを示す。CD44の腫瘍促進作用 については以前から議論のあるところであった。大腸癌などで はバリアントエキソン v6 をもつ CD44 の発現が増加し、これ が転移や患者の予後と相関するとされてきたが、卵巣癌や前立 腺癌ではバリアントエキソン v6 をもつ CD44 が発現する症例 のほうがむしろ予後がよい (35、36)。アンチセンス cDNA で CD44 の発現を抑えると大腸癌細胞では悪性度の低下が見られる (37)のに対し、前立腺癌細胞にCD44 遺伝子を導入すると転移 が抑制される $(38 、 39)$ 。うした矛盾点を説明するためにいろい ろと仮説が提唱されている (40)。

こうした今日までの成績から、CD44 は個体発生や生命の維 持に不可欠な分子ではないものの、さまざまな生理的ないし病 理的過程に強力な影響を与えていると考えられる。 


\section{Effect of Glycosylation on Hyaluronic Acid Binding of CD44}

Although some earlier assumptions on the role of CD44 in inflammatory and malignant diseases may need partial revision, it remains clear that the binding of CD44 to hyaluronic acid has the central role when CD44 exerts biological functions.

Glycosylation of CD44 has been generally assumed to confer an inhibitory effect on its hyaluronic acid binding. For instance, chondroitin sulfate modification of CD44H was shown to inhibit hyaluronic acid binding, because chondroitinase $\mathrm{ABC}$ treatment or inhibition of chondroitin sulfate synthesis with $p$ nitrophenyl $\beta$-xylopyranoside enhanced hyaluronic acid binding (41). Keratan sulfate modification of $\mathrm{CD} 44 \mathrm{H}$ was also inhibitory, since $\mathrm{CD} 44 \mathrm{H}$ in colon cancer cells having keratan sulfate modification showed a reduced hyaluronic acid binding, and keratanase treatment of the cells and CD44-Ig prepared from such cells resulted in enhanced hyaluronic acid binding (42). Tunicamycin- or $N$-glycanase treatment of the cells sometimes led to the enhanced hyaluronic acid binding of CD44 $(41,43)$. Mutation of certain $N$-glycosylation sites was found to enhance hyaluronic acid binding activity of CD44H in some cells (44). Inhibition of $O$-glycosylation also enhanced hyaluronic acid binding of CD44H in colon cancer cells (45).

Glycosylation at the non-conserved region in CD44 variant is also reportedly inhibitory. Use of glycosylation inhibitors for cells expressing CD44E or CD44E-Ig from such cells enhances hyaluronic acid binding, and replacement of the variable exons $\mathrm{v} 8-\mathrm{v} 10$ with the sequence without potential glycosylation sites also did so (46). Replacement of v8-v10 with CD34 mucin domain, which is heavily modified by $O$-glycans, resulted in much weaker binding, suggesting that $O$-glycans in variable exons also have an inhibitory effect (46).

The effect of $\mathrm{N}$ - and $\mathrm{O}$-glycosylation on the hyaluronic acid binding activity of CD44 is in fact, however, bifarious and depends on the types of cells used in the experiments. Tunicamycin treatment of cells, or $\mathrm{N}$-glycanase treatment of CD44-Ig sometimes results in a reduction of CD44-mediated hyaluronic acid binding $(47,48)$. Mutation of any one of five $\mathrm{N}$ glycosylation sites has been found to result in the loss of hyaluronic acid binding activity of CD44H (47). Even mutations in the Ser-Gly motifs were shown to abrogate hyaluronic acid binding in some cells (47). These apparent discrepancies allow various interpretations and explanations. One can assume that some specific carbohydrate structures are required for supporting hyaluronic acid binding activity of CD44, while some other carbohydrate structures are inhibitory, even if the carbohydrate chains were attached at the same position in the CD44 protein core. If so, the experimental outcome would rely on the status of carbohydrate synthetic pathway in the given cells.

Skelton et al. (49), using ldl-D CHO mutant, which relies solely on extracellular galactose for galactosylation of cell

\section{CD44 のヒアルロン酸結合能に対する糖鎖修飾の役割}

炎症や腫瘍を増悪させるというこれまでの CD44 について の考え方は再検討を要するものの、CD44 分子が生理作用を及ぼ す際に、この分子のヒアルロン酸との結合性が中心的な役割を 演じることは明かである。

CD44 の糖鎖修飾は一般的にヒアルロン酸との結合性を抑制 すると考えられてきた。たとえばコンドロイチナーゼ $\mathrm{ABC}$ 処理 や p-nitrophenyl $\beta$-xylopyranoside によるコンドロイチン硫酸の合 成阻害によってヒアルロン酸との結合性が上昇することから、 $\mathrm{CD} 44 \mathrm{H}$ のコンドロイチン硫酸鎖による修飾はヒアルロン酸との 結合を抑制するとされた (41)。ケラタン硫酸鎖も抑制的と考え られている。というのは、ケラタン硫酸鎖によって修飾された 大腸癌細胞の CD44H はヒアルロン酸結合性が低く、この細胞 から得られた CD44-Ig をケラタナーゼ処理するとヒアルロン酸 との結合性が上昇するからである (42)。ッニカマイシンでN-グ リカンの合成を阻害しても CD44 のヒアルロン酸との結合能は

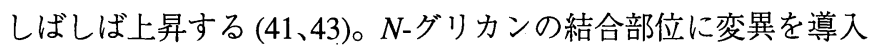
して糖鎖が付かないようにすると、一部の細胞では CD44H の ヒアルロン酸結合能が増大する (44)。O-グリカンの合成阻害に よっても結合能が増大することが知られている (45)。

CD44 のバリアントエキソンの糖鎖修飾も一般に抑制的であ る。糖鎖合成阻害剂を用いると上皮細胞の CD44E やそれらの細 胞から得られた CD44E-Ig のヒアルロン酸結合能は増大するし、 バリアントエキソン $\mathrm{v} 8 \sim \mathrm{v} 10$ を糖鎖結合性のないシクエンスで 置き換えるとヒアルロン酸結合能は増大する $(46)$ 。逆にバリア ントエキソン $\mathrm{v} 8 \sim \mathrm{v} 10$ を $O$-グリカン糖鎖結合性のある CD34の ムチン領域のシクエンスで置き換えるとヒアルロン酸結合能は 著明に減弱することから、O-グリカン糖鎖もまた抑制的に働く ことがわかる $(46) 。$

実は $N$-およびO-グリカンのヒアルロン酸結合能に対する影 響はもっと複雑で、実験に用いる細胞によっては結果が反対に なることもある。ツニカマイシンで $N$-グリカンの合成を阻害し たり $N$-グリカナーゼ処理したりするとヒアルロン酸結合性の減 弱する細胞がしばしばある $(47 、 48)$ 。ヒアルロン酸結合領域の $N$ グリカンの結合部位に変異を入れて糖鎖が結合しないようにす るとかえって CD44H のヒアルロン酸結合性が消失するとの報 告もある (47)。グリコサミノグリカン鎖の結合部位 Ser-Gly モ チーフの変異によっても、細胞によってはヒアルロン酸結合性 が低下する (47)。こうした実験成績の大きな食い違いにはいろ いろな説明が可能である。ひとつの説明は、たとえ CD44 のコ ア分子中の同じ部位に結合していようとも、ある特定の構造の 糖鎖はヒアルロン酸結合を支持し、他の特定の構造の糖鎖はヒ アルロン酸結合を阻害すると仮定することである。もしそうな ら、実験に使っている細胞がもともとどちらのタイプの糖鎖を 合成発現しているかによって、実験の結果は正反対になってし 
surface glycoproteins including CD44, showed that lack of galactosylation on $\mathrm{N}$-glycans of CD44 enhances hyaluronic acid binding, while galactosylation followed by sialylation inhibits the hyaluronic acid binding. These observations led to the conclusion that $N$-glycans carrying NeuAc $\alpha 2 \rightarrow 3 \mathrm{Gal} \beta 1 \rightarrow$ 4 GlcNAc $\beta$ is inhibitory. Sialidase treatment, presumably resulting in the production of Gal $\beta 1 \rightarrow 4$ GlcNAc $\beta$ terminus on $N$ glycans, markedly enhances the hyaluronic acid binding activity. On the other hand, supply of extracellular GalNAc for synthesis of $O$-glycans in ldl-D CHO cells led to an enhanced hyaluronic acid binding, suggesting $O$-glycans also heighten the binding. Terminal sialylation seemed to have no effect with regard to $O$-glycans (49). These $N$ - and $O$-glycan modifications greatly affected the hyaluronic acid binding of CD44, inducing up to a 30-fold change in the affinity of CD44 for hyaluronic acid. These results established the importance of the specific carbohydrate structures in the regulation of CD44 affinity to hyaluronic acid.

\section{E. Involvement of Endogenous Sialidase}

CD44 on most cell types does not constitutively bind hyaluronic acid, and a number of experimental systems have demonstrated that the hyaluronic acid binding property of CD44 is activation-dependent. Katoh et al. (50) provided the first evidence suggesting the involvement of endogenous sialidase in the LPS-induced activation of hyaluronic acid binding of CD44 in THP-1 cells and peripheral blood monocytes. Like some other cells, sialidase treatment markedly enhanced CD44-mediated hyaluronic acid binding of THP- 1 cells, and also that of a minor population of peripheral blood monocytes. Induction of significant sialidase activity was detected in LPS-treated THP-1 cells. Inclusion of a sialidase inhibitor, 2-deoxy-2,3-dehydro$\mathrm{N}$-acetylneuraminic acid (NeuAc2en), in culture medium during LPS stimulation completely abrogated the increment of hyaluronic acid binding activity. Among endogenous sialidase isoenzymes, a lysosomal sialidase encoded by NEU1 (51) was proposed to be responsible for the observed phenomenon. This enzyme, encoded by a single gene located in the major histocompatibility complex locus, exists in two intracellular pools, soluble and membrane-bound (52). NEU1 is an inducible enzyme, and a several-fold increase of the sialidase activity reportedly occurs in association with activation of lymphoid cells (53).

TNF- $\alpha$ is known to be a positive regulator of the hyaluronic acid binding of CD44 on monocytes, whereas several other cytokines such as IL-4 and IL-13 are negative regulators $(54,55)$. TNF- $\alpha$ treatment of cells resulted in a 5-10 kDa decrease in the molecular mass of $\mathrm{CH} 44 \mathrm{H}$, probably due to carbohydrate remodeling, and IL-4 reversed the decrease (55). The LPS-induced increment of hyaluronic acid binding of CD44 in THP-1 cells is also mediated by TNF- $\alpha$ endogenously produced in the
まうわけである。

CHO 細胞の Idl-D 変異株は、およそあらゆる糖蛋白質のガ ラクトース部分の合成に、細胞外からのガラクトースの供給を 必要とする細胞である。Skeltonら (49) はこの細胞を使って実験 し、CD44の $N$-グリカンがガラクトース残基を欠く場合にはヒ アルロン酸結合能が増大し、ガラクトースやさらにシアル酸残 基が付加するとヒアルロン酸結合能が減弱することを見いだし た。すなわち、NeuAc $\alpha 2 \rightarrow 3 \mathrm{Gal} \beta 1 \rightarrow 4 \mathrm{GlcNAc} \beta$ 構造をもつN-グ リカンはヒアルロン酸結合を阻害する。これをシアリダーゼ処 理すると末端構造は Gal $1 \rightarrow 4 \mathrm{GlcNAc} \beta$ となるはずであるが、こ れはヒアルロン酸結合能を著明に増大させた。またこの細胞に 細胞外から $N$-アセチルガラクトサミンを供給して $O$-グリカンを 合成させるとヒアルロン酸結合能が著明に増大した。O-グリカ ンの場合には末端のシアル酸残基は影響があまりないようであ る(49)。これらの $N$-、O-グリカン糖鎖の修飾によるアルロン酸 結合能の変化はたいへん大きく、結合親和性に 30 倍近い差が観 察されたという。この実験は、糖鎖の特定の構造の違いがCD44 のヒアルロン酸結合能に著明な影響を与えることを明らかにし た。

\section{E. 内因性シァリダーゼの関与}

大多数の細胞では、通常は CD44 はヒアルロン酸結合性を 示さず、刺激によって細胞を活性化させるとはじめて結合能を あらわす。このことはこれまで多くの実験によって明らかに なっている。Katoh ら (50) は、単球系の THP-1 細胞や正常末梢 血の単球の CD44 の、LPS-刺激に伴うヒアルロン酸結合能の誘 導において、内因性シアリダーゼが重要な役割を演じることを をはじめて明らかにした。LPS-刺激によって内因性シアリダー ゼの増加が観察され、CD44 のヒアルロン酸結合能が誘導され た。シアリダーゼ阻害剤である 2-deoxy-2,3-dehydro- $N$ acetylneuraminic acid (NeuAc2en) を加えておくとヒアルロン酸結 合能の誘導が阻止された。内因性シアリダーゼのうち、おそら くNEU1 遺伝子 (51) でコードされるリソゾーム性シアリダーゼ がはたらいているのではないかと推定されている。この酵素の 遺伝子は MHC 遺伝子複合体の近くに位置しており、酵素蛋白 質は細胞内では可溶性画分と膜結合性画分の両方に分布すると される (52)。リンパ球系細胞などの活性化に伴って数倍上昇す るとされ、誘導性の酵素である (53)。

TNF- $\alpha$ もまた単球系細胞の CD44 のヒアルロン酸結合能を 誘導するが、IL-4 や IL-13 などのサイトカインはこれを阻害する (54、55)。TNF- $\alpha$ は CD44 分子量の 5 10 kDa 程度の減少を引き 起こすが、これは拉そらく糖鎖のリモデリングのためであろう。 IL-4 添加によってこの分子量の減少はもとにもどる (55)。先に 述べた LPS-刺激に伴う THP-1 細胞でのヒアルロン酸結合能の誘 導も、LPS-刺激によって内因性に TNF- $\alpha$ の産生が誘導された結 
cells (56). TNF- $\alpha$ induces phosphorylation of $\mathrm{p} 38$ and $\mathrm{p} 42 / 44$ MAPK, and this is involved in the induction of endogenous sialidase activity, because a pyridinyl imidazole p38MAPK inhibitor, SB202190, and the p42/44 MAPK inhibitor, PD98059, both abrogated endogenous sialidase induction and hyaluronic acid binding (56).

The enhancing effect of sialidase on the hyaluronic acid binding activity of CD44 depends on the cell type used. Katoh et al. (43) found 2 out of 5 cell lines and Catterall et al. (48) showed 2 out of 4 which exhibited the induction of hyaluronic acid binding activity after sialidase treatment, while other cell lines did not $(41,44,57)$. This would imply that a mechanism involving other than sialic acid residues may also be involved in the activation of hyaluronic acid binding activity; for instance, the enhancing effect exerted by $O$-glycans on hyaluronic acid binding activity had no demonstrable relation to sialic acid residue (49).

\section{F. Role of Carbohydrate Sulfation}

Johnson and colleagues discovered that some sulfate modification of the CD44 molecule is also intimately involved in the hyaluronic acid binding in activated leukocytes (58). TNF$\alpha$ treatment of myelogenous leukemia cells SR91 resulted in enhanced hyaluronic acid binding mediated by CD44, which was accompanied by a marked increase in sulfation of the CD44 molecule. The enhancement in hyaluronic acid binding was abrogated in the presence of the sulfation inhibitor, chlorate $\left(\mathrm{NaClO}_{3}\right)$. The increased hyaluronic acid binding activity of CD44 on peripheral blood monocytes stimulated with TNF- $\alpha$ or IFN- $\gamma$ was also shown to depend on sulfation (59). As chlorate inhibits cellular uptake of sulfate and blocks its activation through PAPS synthesis, this treatment affects protein sulfation as well as carbohydrate sulfation. It was not clear from these studies whether protein sulfation such as tyrosine sulfation, or carbohydrate sulfation, or both were involved in the inhibition of hyaluronic acid binding induction.

In another experimental system where human lung cancer cell lines were employed, oncostatin $M$ and TGF- $\beta$ were shown to enhance CD44-mediated hyaluronic acid binding (60). Not the action of TGF- $\beta$, but that of oncostatin M was accompanied by a marked increase in sulfate incorporation of CD44, and the increment of hyaluronic acid binding was inhibited again by chlorate (60). Apart from leukocytes, these cancer cells expressed a significant amount of high molecular weight CD44 variants in addition to $\mathrm{CD} 44 \mathrm{H}$. Since the increase of sulfate incorporation was more prominent in the high molecular forms of CD44, the enhanced hyaluronic acid binding was ascribed to the increased sulfation of chondroitin sulfate carried by variant exons in these cancer cells (60).

On the other hand, in the experimental system employing leukemic SR91 cells, TNF- $\alpha$-induced oversulfation was
果であると考えられる (56)。TNF- $\alpha$ は 38 と $\mathrm{p} 42 / 44$ の MAPK の リン酸化を誘導するが、これが内因性シアリダーゼの誘導に関与 しているようである。p38 MAPK 阻害剤の SB202190やp42/44 MAPK 阻害剤の PD98059 が内因性シアリダーゼの誘導やヒアル ロン酸結合能の誘導を阻止するからである (56)。

シアリダーゼを介したヒアルロン酸結合能の誘導もすべて の細胞に見られるわけではなく、実験に用いた細胞に依存す る。Katohら (43) は用いた 5 種の細胞のうち 2 種に、また Catterall ら (48) は用いた 4 種の細胞のうち 2 種に観察されたと している $(41 、 44 、 57) 。$ 他の細胞においては、シアリダーゼ以外 のメカニズムが主にはたらいていると考えられる。たとえば上 述のように、シアル酸残基は $O$-グリカン糖鎖によるヒアルロン 酸結合能の充進の場合にはあまり関与していないと考えられて いる (49)。

\section{F. CD44 糖鎖の硫酸化の意義}

Johnson らは何らかの硫酸基修飾が活性化白血球におけるヒ アルロン酸結合能の誘導に深く関与していることを見いだした (58)。ヒト白血病細胞 SR91を TNF- $\alpha$ で刺激すると CD44 のヒ アルロン酸結合能が誘導されるが、このとき CD44 分子に活発 に硫酸基が取り込まれる。細胞の硫酸基代謝を阻害する塩素酸 ナトリウム $\left(\mathrm{NaClO}_{3}\right)$ を培地に添加して扔くと、ヒアルロン酸結 合能の誘導は阻止される。TNF- $\alpha$ や IFN- $\gamma$ で刺激した末梢血の 単球に扔ける CD44 のヒアルロン酸結合能の誘導もやはり硫酸 基に依存していることがあきらかになった (59)。塩素酸ナトリ ウムは硫酸基の細胞への取り込みと PAPS への活性化を阻止す るので、蛋白質の硫酸化も糖鎖の硫酸化も阻止される。このた め、この実験からは蛋白質の硫酸化が大切なのか、糖鎖の硫酸 化が大切なのか、あるいは両方とも大切なのかが明かでなかっ た。

ヒトの肺癌細胞を使った実験では、oncostatin M と TGF- $\beta$ が ヒアルロン酸結合能を誘導するが、このうち oncostatin M は CD44 の硫酸化を六進させ、これを塩素酸ナトリウムで阻害する とヒアルロン酸結合能の誘導が阻止されることがわかった (60)。白血球とは異なり、癌細胞の場合は CD44H に加えて高分 子量の CD44 バリアントを発現しており、硫酸基の添加は高分 子量のバリアントに強く観察されたので、バリアントエキソン 部分のコンドロイチン硫酸糖鎖の過硫酸化がヒアルロン酸結合 能の増加をもたらしているのではないかと考察されている $(60)$ 。

一方、白血病細胞 SR91 の TNF- $\alpha$ による刺激では、グリコ サミノグリカン鎖ではなく、主として $N$ - および $O$-グリカン糖 鎖部分の硫酸化が元進することがわかった (61)。特に 6-硫酸化 ラクトサミンすなわち $\mathrm{Gal} \beta 1 \rightarrow 4 \mathrm{GlcNAc} \beta[6-O$-sulfate $1 \rightarrow \mathrm{R}$ 構造 を特異的に認識する単クローン抗体 AG107 によって検出される 
mainly observed in $\mathrm{N}$ - and $\mathrm{O}$-glycans rather than glycosaminoglycan chains (61). Interestingly, in TNF- $\alpha$-treated SR91 cells, a significant increase of the sulfated carbohydrate determinant defined by a monoclonal antibody AG107, which defines 6-sulfated $N$-acetyl lactosamine (6-sufo LacNAc) having the structure, Gal $\beta 1 \rightarrow 4 \mathrm{GlcNAc} \beta[6-O$-sulfate] $1 \rightarrow \mathrm{R}$, was detected. This type of GlcNAc 6-sulfation was previously shown to be involved in the recognition of another cell adhesion system, L-selectin (62), which mediates leukocyte extravasation as well as CD44 (63). Transcription of GlcNAc-6-sulfotransferase (GlcNAc6ST1 ) is known to be induced by inflammatory cytokines (64).

\section{G. Distribution of Non-Sialylated 6-Sulfated Determinants}

Although the loss of sialylation and induction of 6 sulfation upon activation is not observed in every experimental system, it is tempting to speculate that, in certain cell lineages, activation of cells with inflammatory cytokines would elicit both desialylation and sulfation. This would lead to production of the non-sialylated but 6-sulfated carbohydrate structure such as 6-sulfo LacNAc in $\mathrm{N}$ - and/or $O$-glycans of CD44 molecules, conferring much enhanced CD44-mediated hyaluronic acid binding on the cells.

Introduction of the genes for 6-sulfotransferases to cells, which was repeatedly performed during the course of elucidation of the role of 6-sulfation in selectin-mediated cell adhesion $(64,65)$, usually results in the expression on the cells of fully sialylated 6-sulfo determinants such as sialyl 6-sulfo LacNAc. Preferential expression of non-sialylated but 6-sulfated carbohydrate determinants on the given cells, if any, would be rather extraordinary or unusual, and can not be achieved by merely up-regulating the expression of sulfotransferase genes.

The search for human peripheral leukocytes for the cells expressing the non-sialylated and 6-sulfated determinant, 6-sulfo LacNAc, yielded a minor but distinct subset of activated dendritic cells. A monoclonal antibody, M-DC8, raised against lineage marker-negative human peripheral blood mononuclear cells, defines a small subset of dendritic cells, which comprises 1$2 \%$ of mononuclear leukocytes in human peripheral blood (66, $67)$. This antibody was shown to specifically recognize the nonsialylated but 6 -sulfated LacNAc determinant, Gal $\beta 1 \rightarrow$ 4 GlcNAc $\beta[6-O$-sulfate $] 1 \rightarrow \mathrm{R}$ (68) (Fig. 4). Subsequently, a second-generation antibody DD-1 was raised against peripheral blood dendritic cells sorted using M-DC8, and a more specific third-generation antibody DD-2 was obtained using DD-1-positive dendritic cells as immunogen. All these antibodies specifically recognized 6-sulfo LacNAc (Fig. 4). The first-generation antibody M-DC8 was moderately cross-reactive to disulfated determinants such as 6,6'-disulfo LacNAc Gal $\beta$ [6- $O$-sulfate] $1 \rightarrow 4 \mathrm{GlcNAc} \beta[6-O$-sulfate] $1 \rightarrow \mathrm{R}$, but this cross reactivity was markedly reduced in the second-generation antibody DD-1, and diminished in the third-generation antibody DD-2 (Fig. 4), which
糖鎖が、TNF- $\alpha$ 刺激後の SR91 細胞で有意に増加する (61) こと は注目に值する。この N-アセチルグルコサミンの 6-硫酸化を含 む構造の糖鎖は、以前から CD44 と同じく白血球の血管外動員 に関与する細胞接着系である L-セレクチンを介した細胞接着に 深く関与することが明かとなっているものである $(62 、 63) 。$ 炎症 性サイトカイン刺激にともなって $N$-アセチルグルコサミンの 6硫酸基転移酵素の転写が増大することもすでに知られている (64)。

\section{G. シアル酸残基を持たない 6-硫酸化糖鎖を発現する細胞}

細胞の刺激に伴って CD44 糖鎖の脱シアル酸化と 6-硫酸化 が扔こり、これが CD44 のヒアルロン酸結合能の誘導に関与す ることは、すべての実験系で常に観察されるとは限らないけれ ども、もし細胞でこの両方の変化が同時に起こったら、より効 率的にヒアルロン酸結合能の誘導がおこることを推定させる。 このような変化が同時に起これば、シアル酸の付いていない6硫酸化ラクトサミン糖鎖が $N$ - ないしは $O$-グリカンに発現され ることになるであろう。

$N$-アセチルグルコサミンの 6 位に硫酸基を転移する酵素の 遺伝子を細胞に導入する実験はセレクチンの糖鎖リガンドを研

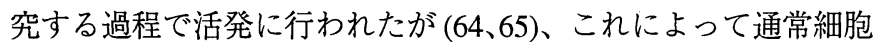
表層に発現するのはシアル酸の付加した 6-硫酸化糖鎖である。 シアル酸の付いていない 6-硫酸化糖鎖の発現が優位であるよう な事象は尋常ではなく、そのような状態はただ 6-硫酸基転移酵 素の発現がふえるだけでは扔こらない。

いったいシアル酸の付いていない 6-硫酸化糖鎖、たとえば 6-硫酸化ラクトサミンを有意に発現するような細胞があるのか どうかをヒトの末梢血白血球で調べてみると、ごく少数の樹状 細胞の前駆細胞と見られる細胞だけがこれを発現することがわ かった。樹状細胞に対する抗体を作る目的で、既知の白血球サ ブセットのマーカーを持たないヒトの末梢血単核球に対して作 成された単クローン抗体 M-DC8 は、末梢血単核球の約 1 2\%

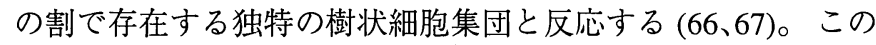
抗体がシアル酸を持たない 6-硫酸化ラクトサミン、Galß1 $4 \mathrm{GlcNAc} \beta[6-O$-sulfate $] 1 \rightarrow \mathrm{R}$ を特異的に認識することが明らかに なった (図 4) (68)。M-DC8 抗体陽性の樹状細胞を集めて免疫原 として用いて作成した第二世代の抗体 DD-1 も、さらにDD-1 抗 体陽性細胞を用いて得られた第三世代の抗体 DD-2 もすべてシ アル酸を持たない6-硫酸化ラクトサミンを認識していた(図 4)。 第一世代の M-DC8 抗体は硫酸基を二個有する 6,6'二硫酸化ラ クトサミン、Gal $\beta[6-O$-sulfate $] 1 \rightarrow 4 \mathrm{GlcNAc} \beta[6-O$-sulfate $] 1 \rightarrow \mathrm{R}$ と 

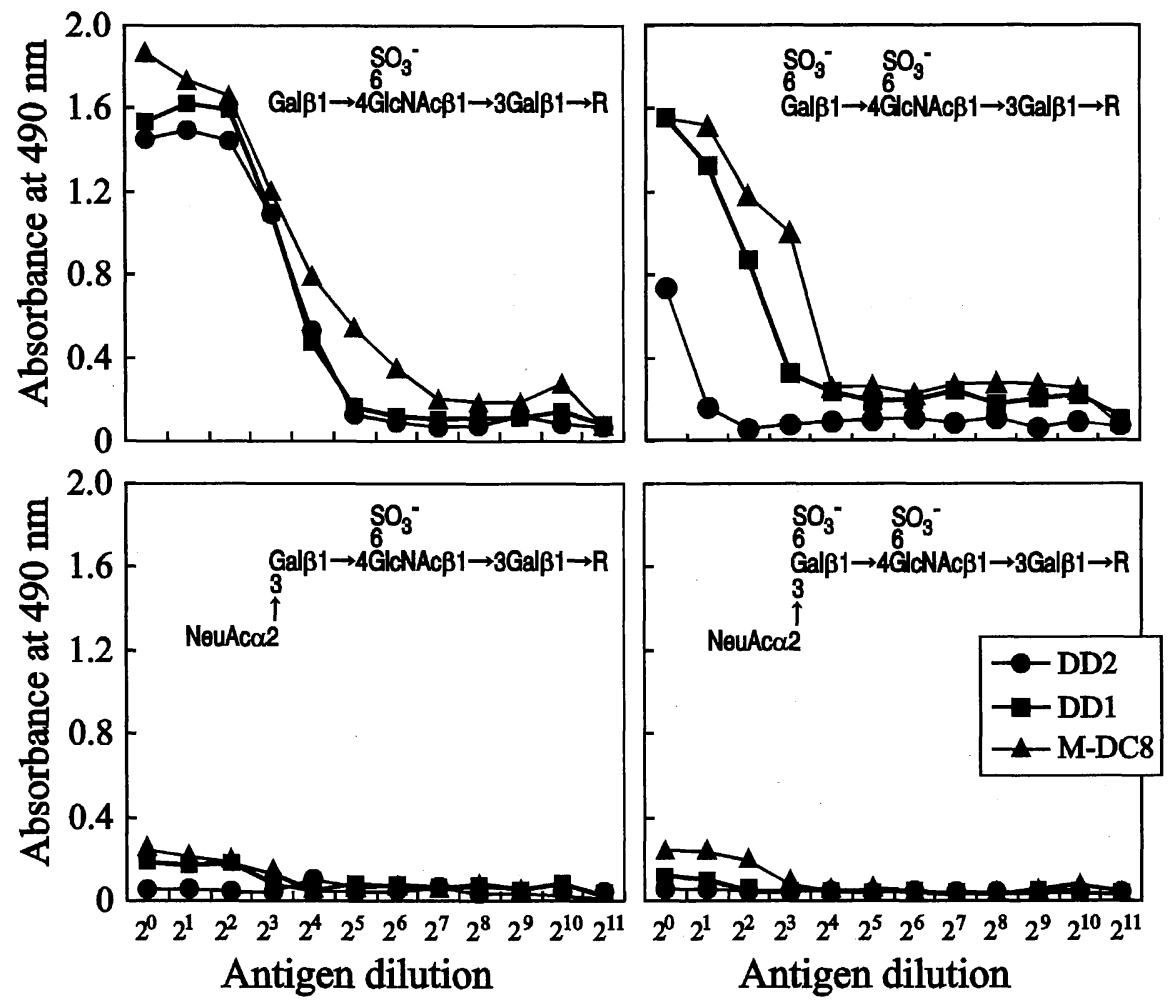

Fig. 4. Specific recognition of 6-sulfo LacNAc by anti-dendritic cell antibodies, M-DC8, DD-1 and DD-2. The first generation antibody M-DC8 was moderately cross-reactive to the disulfated determinant 6,6'-disulfo LacNAc, but this cross reactivity was markedly reduced in the second generation antibody DD-1, and diminished in the third-generation antibody DD-2. These antibodies were specific to non-sialylated determinants, and not reactive to sialylated determinants as shown in the lower panels.

still fully retained the reactivity to the non-sialylated and monosulfated determinant, 6-sulfo LacNAc, as well as the reactivity to the human peripheral blood dendritic cell subset. None of these antibodies ever cross-reacted with any sialylated counterparts having the same core structure. To exclude the possibility that the dendritic cell specificity of these antibodies might depend on the simultaneous recognition of peptide portions of some dendritic cell-specific surface sulfoglycoproteins, an anti-6-sulfo LacNAc antibody raised against a synthetic carbohydrate determinant was tested for peripheral blood leukocytes. The antibody raised against the pure synthetic 6-sulfo LacNAc determinant clearly defined essentially the same dendritic cell population in peripheral blood as detected by M-DC8 series antibodies, indicating this unique non-sialylated 6-sulfated determinant really defines these dendritic cell populations.

These antibodies enabled direct isolation of a unique population of dendritic cells by a one-step immunomagnetic procedure from fresh mononuclear cells, which expressed HLA class II molecules, CD33, and the co-stimulatory molecules such as CD86 and CD40. These cells displayed an outstanding capacity to present antigens to naïve helper $T$ cells, and induced differentiation of cytotoxic $\mathrm{T}$ cells. These cells strongly expressed Fc $\gamma$ RIII (CD16) and Fc $\gamma$ RII (CD32), and exhibited sig-
中程度の交差反応性を示したが、世代を重ねるごとにこの交叉 反応性は減少し、第三世代の抗体 DD-2 では交叉反応性は完全 に消失した (図 4)。しかしこの第三世代の抗体は硫酸基が一個 の 6-硫酸化ラクトサミンとはよく反応し、また第一世代の抗体 と同じ樹状細胞集団を検出した。これらの抗体はシアル酸の付 いた糖鎖とは全て反応しない。これらの抗体が樹状細胞を特異 的に識別するのが、これらの糖鎖を担うコア蛋白質の一部をも 認識しているためである疑いを払拭するため、合成の純品 6-硫 酸化ラクトサミン糖鎖を免疫原とした抗体をヒト末梢血白血球 と反応させたところ、はたして全く同じ集団の樹状細胞を検出 することがわかった。このことから、このアシアロ型の 6-硫酸 化糖鎖が、たしかにこの樹状細胞を定義づける特有のものであ ることが確認できた。

これらの抗体を用いることにより、ヒト末梢血から磁気 ビーズ法によってワンステップの操作で樹状細胞を精製でき る。こうして集めた樹状細胞は HLA クラス II 抗原、CD33、 $\mathrm{CD} 86$ や CD40 を発現し、ナイーブヘルパー $\mathrm{T}$ 細胞への強い抗 原提示能とキラー $\mathrm{T}$ 細胞の分化誘導能を持つ。また Fc $\gamma \mathrm{R} I I I$ 
nificant cytotoxicity in ADCC (69). While the phenotypical analysis revealed similarities with the two well-known dendritic cell populations, DC1 and DC2, the characteristic expression of Fc $\gamma$ RIII (CD16), so far not found on known dendritic cell populations, and that of the non-sialylated 6-sulfo LacNAc determinant clearly defined them as a distinct population of blood dendritic cells. Besides peripheral blood, the dendritic cells bearing 6-sulfo LacNAc determinant are found in tonsils and Peyer's patches, but far less frequently in spleen and lymph nodes (70). In the tonsils they are predominantly located in the $\mathrm{T}$ cell zone, right beneath the squamous epithelial cells of the tonsillar crypts (70). In the intestine, they are located in the subepithelial region of the dome in Peyer's patches (70).

The dendritic cells bearing the non-sialylated 6-sulfo LacNAc determinant were shown to efficiently produce $10-14$ times higher levels of TNF- $\alpha$ by LPS stimulation as compared to monocytes without the determinant (70). Although the hyaluronic acid binding activity of this distinct dendritic cell population remains to be evaluated, it would be of considerable interest to see if CD44 in this population of dendritic cells is preactivated for hyaluronic acid binding. CD44 has been implicated in various dendritic cell functions, including their functional maturation, homing to the draining lymph nodes, and activation of $\mathrm{T}$ cells (71-73). The homing behavior of these cells is of particular interest, since the dendritic cells bearing nonsialylated 6-sulfo LacNAc determinant were recently shown to be particularly active in trans-endothelial migration, and were strongly predisposed to become migratory dendritic cells (74).
(CD16) と FcyRII (CD32) を強く発現し、抗体依存性細胞障害作 用も強い (69)。既知の樹状細胞サブセットである DC1 や DC2 に類似した表面形質を持つが、FcyRIII (CD16) を発現する点や、 6-硫酸化ラクトサミン糖鎖を発現する点はユニークな特徵であ り、これら既知の樹状細胞とは異なる細胞集団である。6-硫酸 化ラクトサミン糖鎖を発現する樹状細胞は末梢血のほかに扁桃 やパイエル板に高頻度に見られ、脾やリンパ節には少ない (70)。扁桃では扁桃窩の扁平上皮の直下に存在し、パイエル板で はいわゆるドーム上皮細胞の直下に存在する (70)。

このアシアロ型の 6-硫酸化ラクトサミン糖鎖を発現する樹 状細胞は活発に TNF- $\alpha$ を産生する (70)。LPS 刺激に際して、こ の糖鎖を発現しない単球に比べておよそ10〜14 倍もの量の TNF- $\alpha$ を産生するとされる (70)。この樹状細胞集団の CD44の ヒアルロン酸結合能はまだ報告されていないが、おそらく強い ヒアルロン酸結合性を持っているであろう。CD44 は樹状細胞の さまざまな挙動、たとえば樹状細胞の分化や、組織内の樹状細 胞の支配域リンパ節へのホーミングや、抗原提示によるT細胞 の活性化の過程に関与するとされている (71-73)。このうち樹状 細胞の支配域リンパ節内へのホーミングは特に興味深い。最 近、このアシアロ型の 6-硫酸化ラクトサミン糖鎖を発現する樹 状細胞は内皮細胞層を出入りする活性が強く、特に活発に動き 回るという特徴をもっていることが判明したからである(74)。

\section{References}

1. Ponta, H., Sherman, L., and Herrlich, P. A. (2003) Nat. Rev. Mol. Cell Biol. 4, 33-45

2. Cichy, J., and Pure, E. (2003) J. Cell Biol. 161, 839-843

3. Dhanji, S., and Teh, H. S. (2003) J. Immunol. 171, 3442-3450

4. Knudson, C. B. (2003) Birth Defects Res. Part. C. Embryo. Today 69, 174-196

5. Isacke, C. M., and Yarwood, H. (2002) Int. J. Biochem. Cell Biol. 34, 718-721

6. Knudson, W., Chow, G., and Knudson, C. B. (2002) Matrix Biol. 21, 15-23

7. Bajorath, J. (2000) Proteins 39, 103-111

8. Peach, R. J., Hollenbaugh, D., Stamenkovic, I., and Aruffo, A. (1993) J. Cell Biol. 122, 257-264

9. Bajorath, J., Greenfield, B., Munro, S. B., Day, A. J., and Aruffo, A. (1998) J. Biol. Chem. 273, 338-343

10. Greenfield, B., Wang, W. C., Marquardt, H., Piepkorn, M., Wolff, E. A., Aruffo, A., and Bennett, K. L. (1999) J. Biol. Chem. 274, 2511-2517

11. Kannagi, R. (2004) Glycoconjugate J., in press

12. Kannagi, R.(2003) in Carbohydrate-based Drug Discovery (Wong, C. H., Ed.), pp. 803-829, Wiley-VCH Verlag GmbH \& Co., Weinheim, Germany

13. Kannagi, R. (1997) Glycoconjugate J. 14, 577-584

14. Schmits, R., Filmus, J., Gerwin, N., Senaldi, G., Kiefer, F., Kundig, T., Wakeham, A., Shahinian, A., Catzavelos, C., Rak, J., Furlonger, C., Zakarian, A., Simard, J. J., Ohashi, P. S., Paige, C. J., Gutierrez-Ramos, J. C., and Mak, T. W. (1997) Blood 90, $2217-2233$

15. Protin, U., Schweighoffer, T., Jochum, W., and Hilberg, F. (1999) J. Immunol. 163, 4917-4923

16. Stoop, R., Kotani, H., McNeish, J. D., Otterness, I. G., and Mikecz, K. (2001) Arthritis Rheum. 44, 2922-2931

17. Stoop, R., Gal, I., Glant, T. T., McNeish, J. D., and Mikecz, K. (2002) Eur. J. Immunol. 32, 2532-2542

18. Camp, R. L., Scheynius, A., Johansson, C., and Pure, E. (1993) J. Exp. Med. 178, 497-507

19. Brennan, F. R., Mikecz, K., Glant, T. T., Jobanputra, P., Pinder, S., Bavington, C., Morrison, P., and Nuki, G. (1997) Scand. J. Immunol. 45, 213-220

20. Casey, R. C., Oegema, T. R.,Jr., Skubitz, K. M., Pambuccian, S. E., Grindle, S. M., and Skubitz, A. P. (2003) Clin. Exp. Metastasis 20, 143152

21. Nomura, M., Sugiura, Y., Tatsumi, Y., and Miyamoto, K. (1999) Biol. Pharm. Bull. 22, 738-740

22. Hosono, J., Narita, T., Kimura, N., Sato, M., Nakashio, T., Kasai, Y., Nonami, T., Nakao, A., Takagi, H., and Kannagi, R. (1998) J. Surg. Oncol. 67, 77-84 
23. Nakashio, T., Narita, T., Akiyama, S., Kasai, Y., Kondo, K., Ito, K., Takagi, H., and Kannagi, R. (1997) Int. J. Cancer 70, 612-618 24. Stoof, T. J., Mitra, R. S., Sarma, V., Dixit, V. M., and Nickoloff, B. J. (1992) J. Invest. Dermatol. 98, 92-95

25. Macdonald, D. C., Leir, S. H., Brooks, C., Sanders, E., Lackie, P., and Rosenberg, W. (2003) Eur. J. Gastroenterol. Hepatol. 15, 1101-1110

26. Cuff, C. A., Kothapalli, D., Azonobi, I., Chun, S., Zhang, Y., Belkin, R., Yeh, C., Secreto, A., Assoian, R. K., Rader, D. J., and Pure, E. (2001)

J. Clin. Invest. 108, 1031-1040

27. Wang, X., Xu, L., Wang, H., Zhan, Y., Pure, E., and Feuerstein, G. Z. (2002) J. Neurochem. 83, 1172-1179

28. Chen, D., McKallip, R. J., Zeytun, A., Do, Y., Lombard, C., Robertson, J. L., Mak, T. W., Nagarkatti, P. S., and Nagarkatti, M. (2001) J. Immunol. 166, 5889-5897

29. Teder, P., Vandivier, R. W., Jiang, D., Liang, J., Cohn, L., Pure, E., Henson, P. M., and Noble, P. W. (2002) Science 296, 155-158

30. Florquin, S., and Rouschop, K. M. (2003) Kidney Int. Suppl. S15-S20

31. Wang, Q., Teder, P., Judd, N. P., Noble, P. W., and Doerschuk, C. M. (2002) Am. J. Pathol. 161, 2219-2228

32. McKallip, R. J., Do, Y., Fisher, M. T., Robertson, J. L., Nagarkatti, P. S., and Nagarkatti, M. (2002) Int. Immunol. 14, 1015-1026

33. Weber, G. F., Bronson, R. T., Ilagan, J., Cantor, H., Schmits, R., and Mak, T. W. (2002) Cancer Res. 62, 2281-2286

34. Assimakopoulos, D., Kolettas, E., Patrikakos, G., and Evangelou, A. (2002) Histol. Histopathol. 17, 1269-1281

35. Sillanpaa, S., Anttila, M. A., Voutilainen, K., Tammi, R. H., Tammi, M. I., Saarikoski, S. V., and Kosma, V. M. (2003) Clin. Cancer Res. 9, 5318-5324

36. De Marzo, A. M., Bradshaw, C., Sauvageot, J., Epstein, J. I., and Miller, G. J. (1998) Prostate 34, 162-168

37. Harada, N., Mizoi, T., Kinouchi, M., Hoshi, K., Ishii, S., Shiiba, K., Sasaki, I., and Matsuno, S. (2001) Int. J. Cancer 91, 67-75

38. Lou, W., Krill, D., Dhir, R., Becich, M. J., Dong, J. T., Frierson, H. F.,Jr., Isaacs, W. B., Isaacs, J. T., and Gao, A. C. (1999) Cancer Res. 59, 2329-2331

39. Verkaik, N. S., van Steenbrugge, G. J., van Weerden, W. M., Bussemakers, M. J., and van der Kwast, T. H. (2000) Lab. Invest. 80, 1291-1298

40. Herrlich, P., Morrison, H., Sleeman, J., Orian-Rousseau, V., Konig, H., Weg-Remers, S., and Ponta, H. (2000) Ann. N. Y. Acad. Sci. 910, 10618; discus.

41. Lesley, J., English, N., Perschl, A., Gregoroff, J., and Hyman, R. (1995) J. Exp. Med. 182, 431-437

42. Takahashi, K., Stamenkovic, I., Cutler, M., Dasgupta, A., and Tanabe, K. K. (1996) J. Biol. Chem. 271, 9490-9496

43. Katoh, S., Zheng, Z., Oritani, K., Shimozato, T., and Kincade, P. W. (1995) J. Exp. Med. 182, 419-429

44. English, N. M., Lesley, J. F., and Hyman, R. (1998) Cancer Res. 58, 3736-3742

45. Dasgupta, A., Takahashi, K., Cutler, M., and Tanabe, K. K. (1996) Biochem. Biophys. Res. Commun. 227, 110-117

46. Bennett, K. L., Modrell, B., Greenfield, B., Bartolazzi, A., Stamenkovic, I., Peach, R., Jackson, D. G., Spring, F., and Aruffo, A. (1995) J. Cell Biol. 131, 1623-1633

47. Bartolazzi, A., Nocks, A., Aruffo, A., Spring, F., and Stamenkovic, I. (1996) J. Cell Biol. 132, 1199-1208

48. Catterall, J. B., Jones, L. M., and Turner, G. A. (1999) Clin. Exp. Metastasis 17, 583-591

49. Skelton, T. P., Zeng, C., Nocks, A., and Stamenkovic, I. (1998) J. Cell Biol. 140, 431-446

50. Katoh, S., Miyagi, T., Taniguchi, H., Matsubara, Y., Kadota, J., Tominaga, A., Kincade, P. W., Matsukura, S., and Kohno, S. (1999) J. Immunol. 162, 5058-5061

51. Milner, C. M., Smith, S. V., Carrillo, M. B., Taylor, G. L., Hollinshead, M., and Campbell, R. D. (1997) J. Biol. Chem. 272, 4549-4558

52. Lukong, K. E., Seyrantepe, V., Landry, K., Trudel, S., Ahmad, A., Gahl, W. A., Lefrancois, S., Morales, C. R., and Pshezhetsky, A. V. (2001) J. Biol. Chem. 276, 46172-46181

53. Naraparaju, V. R., and Yamamoto, N. (1994) Immunol. Lett. 43, 143-148

54. Levesque, M. C., and Haynes, B. F. (1997) J. Immunol. 159, 6184-6194

55. Levesque, M. C., and Haynes, B. F. (1999) Cell Immunol. 193, 209-218

56. Gee, K., Kozlowski, M., and Kumar, A. (2003) J. Biol. Chem. 278, 37275-37287

57. Gal, I., Lesley, J., Ko, W., Gonda, A., Stoop, R., Hyman, R., and Mikecz, K. (2003) J. Biol. Chem. 278, 11150-11158

58. Maiti, A., Maki, G., and Johnson, P. (1998) Science 282, 941-943

59. Brown, K. L., Maiti, A., and Johnson, P. (2001) J. Immunol. 167, 5367-5374

60. Cichy, J., and Pure, E. (2000) J. Biol. Chem. 275, 18061-18069

61. Delcommenne, M., Kannagi, R., and Johnson, P. (2002) Glycobiology 12, 613-622

62. Kannagi, R. (2002) Curr. Opin. Struct. Biol. 12, 599-608

63. Johnson, P., Maiti, A., Brown, K. L., and Li, R. (2000) Biochem. Pharmacol. 59, 455-465

64. Kimura, N., Mitsuoka, C., Kanamori, A., Hiraiwa, N., Uchimura, K., Muramatsu, T., Tamatani, T., Kansas, G. S., and Kannagi, R. (1999) Proc. Natl. Acad. Sci. USA 96, 4530-4535

65. Kanamori, A., Kojima, N., Uchimura, K., Muramatsu, T., Tamatani, T., Berndt, M. C., Kansas, G. S., and Kannagi, R. (2002) J. Biol. Chem. 277, 32578-32586

66. Schakel, K., Mayer, E., Federle, C., Schmitz, M., Riethmuller, G., and Rieber, E. P. (1998) Eur. J. Immunol. 28, 4084-4093

67. Schakel, K., Poppe, C., Mayer, E., Federle, C., Riethmuller, G., and Rieber, E. P. (1999) Pathobiology 67, 287-290

68. Schakel, K., Kannagi, R., Kniep, B., Goto, Y., Mitsuoka, C., Zwirner, J., Soruri, A., von Kietzell, M., and Rieber, E. P. (2002) Immunity 17, 289-301

69. Schmitz, M., Zhao, S., Schakel, K., Bornhauser, M., Ockert, D., and Rieber, E. P. (2002) Blood 100, 1502-1504

70. de Baey, A., Mende, I., Baretton, G., Greiner, A., Hartl, W. H., Baeuerle; P. A., and Diepolder, H. M. (2003) J. Immunol. 170, 5089-5094

71. Termeer, C., Averbeck, M., Hara, H., Eibel, H., Herrlich, P., Sleeman, J., and Simon, J. C. (2003) Immunology 109, 32-40

72. Haegel-Kronenberger, H., de la Salle, H., Bohbot, A., Oberling, F., Cazenave, J. P., and Hanau, D. (1998) J. Immunol. 161, 3902-3911

73. Weiss, J. M., Sleeman, J., Renkl, A. C., Dittmar, H., Termeer, C. C., Taxis, S., Howells, N., Hofmann, M., Kohler, G., Schopf, E., Ponta, H., Herrlich, P., and Simon, J. C. (1997) J. Cell Biol. 137, 1137-1147

74. Randolph, G. J., Sanchez-Schmitz, G., Liebman, R. M., and Schakel, K. (2002) J. Exp. Med. 196, 517-527 


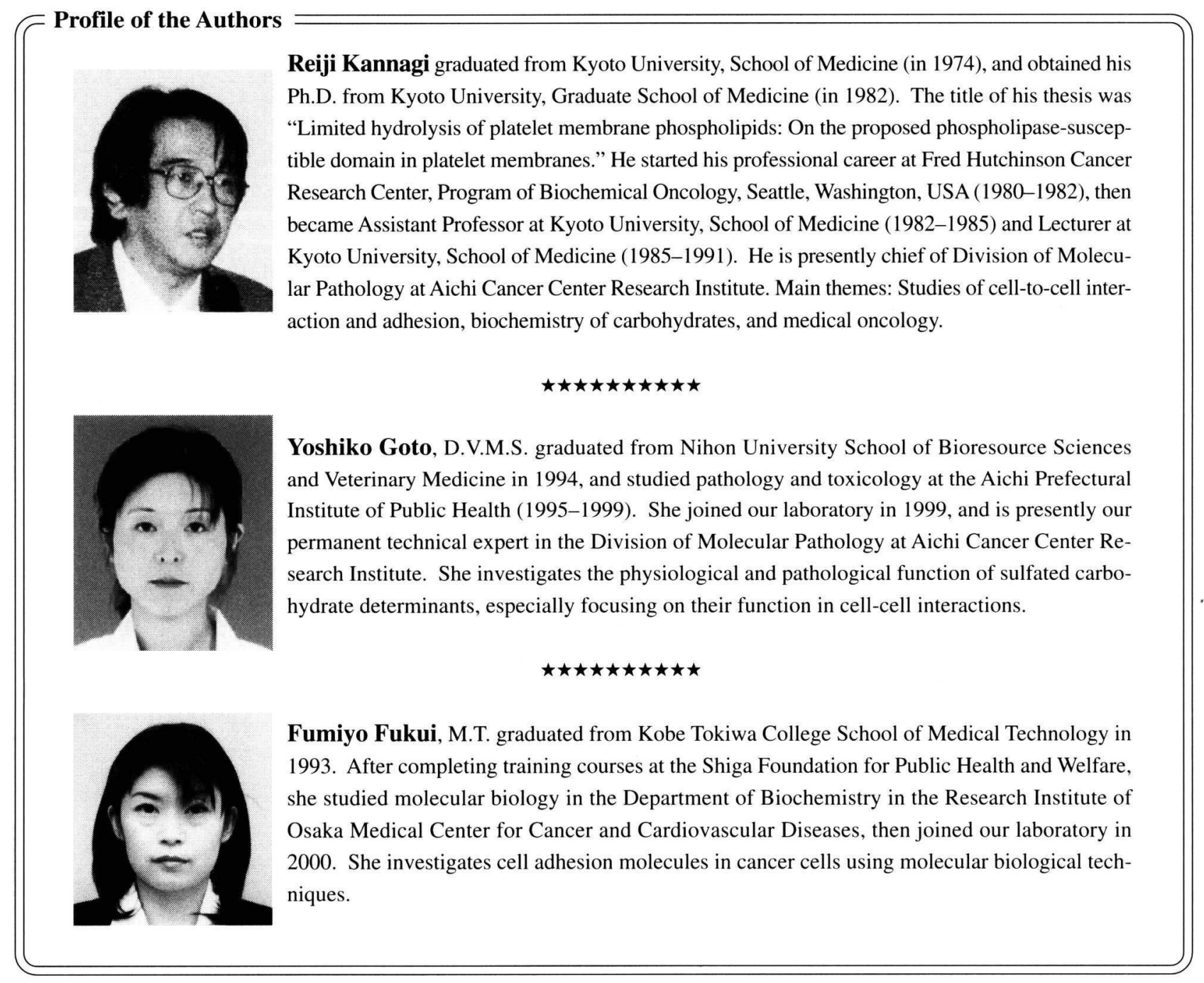

